\title{
The alternation of different morphotypes in the seasonal cycle of the toxic diatom Pseudo-nitzschia galaxiae
}

\author{
Federica Cerino $^{\text {a }}$, Luisa Orsini ${ }^{\mathrm{a}, 1}$, Diana Sarno ${ }^{\mathrm{a}}$, Carmela Dell’ Aversano ${ }^{\mathrm{b}}$, \\ Luciana Tartaglione $^{\mathrm{b}}$, Adriana Zingone ${ }^{\mathrm{a}, *}$ \\ a Stazione Zoologica 'Anton Dohrn', Villa Comunale, Naples 80121, Italy \\ b Dipartimento di Chimica delle Sostanze Naturali, Università degli Studi di Napoli "Federico II", \\ Via D. Montesano 49, 80131 Naples, Italy
}

Received 18 August 2003; accepted 20 October 2003

\begin{abstract}
The marine diatom Pseudo-nitzschia galaxiae Lundholm et Moestrup has been recently described from Mexican and Australian plankton. In this paper, we illustrate the considerable morphological variability of the species in the Mediterranean Sea and present first evidence of its toxicity. In addition to lanceolate cells $25-41 \mu \mathrm{m}$ long, which fit the original description of the species, markedly larger $(<82 \mu \mathrm{m})$ and smaller $(>10 \mu \mathrm{m})$ specimens are commonly recorded. Cells of the largest size have almost parallel valve margins, while smaller specimens have extremely short rostrate ends and do not form colonies. Despite remarkable differences in shape and size, the typical ultrastructure of the species was observed for the different size classes in culture and in natural samples. In culture, cell length decreased at a rate of 1.1-2.1 $\mu \mathrm{m}$ per month. Liquid chromatography-mass spectrometry (LC-MS) analyses revealed the presence of domoic acid (DA) at very low levels in two of seven strains analyzed. LSU rDNA analysis confirmed the identity of the species and showed a very low genetic variability for the strains from the Gulf of Naples, with no relationships with size and overall shape of the cells. A relatively high number (53) of Pseudo-nitzschia sequences were considered in the phylogenetic analysis, yet the relationships among species remain unclear, probably in relation with a recent speciation process in the genus. In natural samples, $P$. galaxiae populations of different cell sizes occurred at different times over the year, with smaller cells found in winter and early spring, and medium and larger cells peaking in late spring-summer. The maximum concentration value in the Gulf of Naples was recorded in May $1985\left(9.4 \times 10^{6}\right.$ cells $\left.^{-1}\right)$. From the analysis of a high number of both natural and culture samples, it is concluded that size and shape variations are indicative of different stages of the life cycle of P. galaxiae, which exhibit a synchronized and seasonal occurrence at the interannual scale.
\end{abstract}

(C) 2004 Elsevier B.V. All rights reserved.

Keywords: Diatoms; Domoic acid; Mediterranean Sea; Phylogeny; Pseudo-nitzschia galaxiae; Taxonomy

\footnotetext{
* Corresponding author. Tel.: +39-081-5833295; fax: +39-081-7641355.

E-mail address: zingone@szn.it (A. Zingone).

${ }^{1}$ Present address: Institut für Tierzucht und Genetik, Veterinärmedizinische Universität Wien, Josef Baumann Gasse 1, 1210 Wien, Austria.
}

\section{Introduction}

The genus Pseudo-nitzschia H. Peragallo includes about 25 species of pennate, colonial marine diatoms. The genus was originally considered as a section of Nitzschia americana H. Hassall (Hasle, 1965), from which it was subsequently separated based on the 
colonial habit and on some ultrastructural features (Hasle, 1995). In recent years, morphological and molecular investigations on Pseudo-nitzschia intensified following the discovery of domoic acid (DA) (Bates et al., 1989), a potent neurotoxic aminoacid that can be accumulated through the trophic web and cause damage to humans, marine mammals and birds (Scholin et al., 2000; Shumway et al., 2003). Nine Pseudo-nitzschia species are currently known to produce DA (Moestrup et al., 2002). Information on the geographic distribution of the genus Pseudo-nitzschia has also grown in recent years. The genus has a worldwide distribution and includes cosmopolitan, temperate and tropical species (Hasle, 2002). Phylogenetic analyses conducted on two different partial LSU rDNA sequence datasets (Lundholm and Moestrup, 2002; Lundholm et al., 2002; Orsini et al., 2002) have shown that the genus Pseudo-nitzschia is paraphyletic (Lundholm et al., 2002), with phylogenetic relationships well resolved at the species level but not at the supraspecific level.

In the Gulf of Naples, Pseudo-nitzschia species were reported, as 'colonial Nitzschia', since the first phytoplankton observations in the area (Schröder, 1901; Issel, 1934). More recently, seven different Pseudo-nitzschia species have been identified in the course of a 15-year sampling programme at a coastal station of the city of Naples (Zingone et al., 2002; Zingone et al., 2003). Among these, very thin morphotypes with a slight central swelling were attributed to Pseudo-nitzschia cf. prolongatoides (Hasle) Hasle. In May 2001, specimens with this lanceolate shape were brought into culture and showed ultrastructural features which were clearly distinct from $P$. prolongatoides and from any other Pseudo-nitzschia species, prompting molecular analysis to clarify phylogenetic relationships. At the same time, morphotypes similar to $P$. cf. prolongatoides from the Gulf of Naples were described as a new species under the name of Pseudo-nitzschia galaxiae (Lundholm and Moestrup, 2002). P. galaxiae has a valve outline slightly swollen in the middle of the cell and tapering towards its ends. The valve ultrastructure is clearly distinctive, due to the lack of poroids that are typical for other Pseudo-nitzschia species, and to the presence of minute pores scattered over the frustule.

In this paper, a wider range of shape and size variability is reported from cultured and field material of
P. galaxiae from the Mediterranean Sea, as compared to the original description. The identity of the species, and its substantial genetic homogeneity is confirmed by LSU analysis. The production of domoic acid is demonstrated for the first time in this species. The role of the life cycle in the seasonal occurrence of the species in the Gulf of Naples is discussed based on the succession of different size classes over the year.

\section{Materials and methods}

\subsection{Cultures}

Six of the seven strains of $P$. galaxiae were obtained from serial dilution cultures (SDC) of natural seawater samples, collected in May 2002 from surface waters at station MC, 2 nautical miles offshore Naples (Table 1). The strain SZN-B58 was isolated from a surface net sample collected at the same station MC in July 2001. In all cases, unicellular cultures were established from a single cell or a single chain of cells and grown in $f / 2$ growth medium, with silica added (Guillard, 1983), prepared with oligotrophic seawater (36 psu) and maintained at a temperature of $15^{\circ} \mathrm{C}$, with a photon irradiance of $70-80 \mu \mathrm{E} \mathrm{m}^{-2} \mathrm{~s}^{-1}$, and in a 12:12 light-dark regime.

For cell enumeration, natural samples were collected fortnightly from 1984 and weekly as of 1995 at the surface in the Gulf of Naples (St. MC), in the framework of a long-term plankton monitoring programme. Samples were fixed with $\mathrm{CaCO}_{3}$-neutralized formaldehyde $0.8 \%$ final concentration and enumerated in the light microscope (Utermöhl, 1958). Small P. galaxiae cells $(10-25 \mu \mathrm{m})$ were enumerated separately from larger cells. Additional Mediterranean

Table 1

List of $P$. galaxiae strains analysed for morphology, domoic acid content and phylogeny

\begin{tabular}{llll}
\hline Strain & Collection data & Isolation data & Sample \\
\hline SZN-B54 & 29 May 2001 & 13 July 2001 & SDC -4II \\
SZN-B55 & 29 May 2001 & 13 July 2001 & SDC -4II \\
SZN-B56 & 29 May 2001 & 13 July 2001 & SDC -4II \\
SZN-B57 & 29 May 2001 & 13 July 2001 & SDC -4II \\
SZN-B58 & 18 July 2001 & 18 July 2001 & Net sample \\
SZN-P1 & 29 May 2001 & 10 January 2002 & SDC -4 V \\
SZN-P5 & 29 May 2001 & 10 January 2002 & SDC -4 V \\
\hline
\end{tabular}


Sea samples from the Open Sicily Channel (October 1991), the Balearic Sea (March 2002), Olbia (Sardinia, Tyrrhenian Sea, June 2002) and Chioggia (Venice, Adriatic Sea, May 2002) were examined. The latter two samples were kindly provided by P. Di Dato (University of Rome, Italy) and R. Casotti (Stazione Zoologica, Naples).

For ultrastructural observation of the frustules, organic matter was eliminated from culture samples using a mixture of $10 \% \mathrm{HNO}_{3}$ and $40 \% \mathrm{H}_{2} \mathrm{SO}_{4}$, followed by rinsing steps with distilled water until all the acid was removed. A drop of the cleaned material was placed on a Formvar-coated grid and observed with a Philips EM 400 microscope. For natural samples, a droplet of fixed uncleaned material was placed on the same kind of grid, dried, rinsed with distilled water and observed as above.

For length measurements, aliquots of cultures of the strains SZN-B54, SZN-B56, SZN-B58, SZN-P1 and SZN-P5 were fixed with $\mathrm{CaCO}_{3}$-neutralized formaldehyde to a final concentration of $0.8 \%$. A subsample of 50 cells per clone were measured monthly over 13 months using a ZEISS Axiophot phase contrast microscope, at a magnification of $400 \times$. Measurements of SZN-P1 and SZN-P5 strains ended beforehand when these cultures died. For the calculations of cell size reduction, measurements of the apical axis were plotted versus time (as julian days). The slope of the straight line that best fits the data, calculated using the least squares method, represents the decrease per day; this value was multiplied by 30 to obtain the monthly decrease value. Length measurements were also taken on subsamples of 50 P. galaxiae cells from each of 11 field samples from the St. MC, corresponding to peak phases of early spring 1996 and 2002 (two samples), mid-spring of 1996-1998 and 2001 (four samples), and summer 1998-2002 (five samples).

\subsection{Toxin analysis}

\subsubsection{Sample extraction}

The cultures examined (Table 2) were concentrated and the resultant pellet was frozen at $-80^{\circ} \mathrm{C}$ until the analysis. The pellet was extracted with a solution of methanol-water 1:1 $(3 \times 250 \mu \mathrm{l})$ and filtered through an Ultrafree-MC $0.45 \mu \mathrm{m}$ membrane (Millipore Ltd., Bedford, MA, USA) at $6000 \mathrm{rpm}$ for $10 \mathrm{~min}$. The
Table 2

$P$. galaxiae material used for domoic acid analysis

\begin{tabular}{lll}
\hline Strain & $\begin{array}{l}\text { Centrifuged } \\
\text { volume }(\mathrm{ml})\end{array}$ & $\begin{array}{l}\text { Number of cells } \\
\left(10^{8} \mathrm{ml}^{-1}\right)\end{array}$ \\
\hline SZN-B54 & 600 & 11.0 \\
SZN-B55 & 609 & 2.1 \\
SZN-B56 & 595 & 6.0 \\
SZN-B57 & 595 & 1.7 \\
SZN-B58 & 600 & 6.5 \\
SZN-P1 & 400 & 7.0 \\
SZN-P5 & 400 & 1.6 \\
\hline
\end{tabular}

volume of the filtrate was adjusted to $900 \mu l$ with extracting solvent and analyzed directly by Liquid chromatography-mass spectrometry (LC-MS). A $450 \mu \mathrm{l}$ aliquot of the extract was evaporated to dryness and subsequently subjected to a SPE clean up using the procedure suggested by Quilliam et al. (1995). Eluates were analyzed by LC-MS.

\subsubsection{Liquid chromatography-mass spectrometry analyses}

High-pressure pump SP model P 4000 (ThermoFinnigan Separation Products, San Jose, CA, USA) coupled to an Applied Biosystem API-2000 triple quadrupole mass spectrometer equipped with a turbo-ionspray source (Thornhill, Ont., Canada), was used for LC-MS experiments. LC separations were performed by using a $5 \mu \mathrm{m}$ TosoHaas TSK-GEL Amide- $80,250 \mathrm{~mm} \times 2 \mathrm{~mm}$, column, isocratically eluted with a $71 \%$ acetonitrile-water solution containing $2 \mathrm{mM}$ ammonium formate and $3.5 \mathrm{mM}$ formic acid, as suggested by Quilliam et al. (2001). The flow rate was $200 \mu \mathrm{min}^{-1}$ and a sample injection volume of $10 \mu \mathrm{l}$ was used. The protonated ion at $\mathrm{m} / \mathrm{z} 312.5$ and the sodium adduct ion at $\mathrm{m} / \mathrm{z} 334.5$ were monitored in positive selected ion monitoring (SIM) experiments, while the $[M-\mathrm{H}]^{-}$ion at $\mathrm{m} / z, 310.5$ was observed in negative SIM. The following groups of six transitions $\mathrm{m} / \mathrm{z} 312 / 294,312 / 266,312 / 248,312 / 220,312 / 193$, $312 / 175$ (collision energy, $30 \mathrm{eV}$ ) and $\mathrm{m} / \mathrm{z} 310 / 266$, $310 / 248,310 / 222$, 310/204, 310/160, 310/82 (collision energy, $-25 \mathrm{eV}$ ) were monitored in positive and negative multiple reaction monitoring (MRM) experiments, respectively. The most abundant transitions $(\mathrm{m} / \mathrm{z} 310 / 266$ and 310/222, negative ion mode) were used for quantitative studies. Direct comparison to standard solutions of domoic acid (Sigma-Aldrich, 
Steinheim, Germany) at similar concentrations injected in the same experimental conditions allowed to determine DA content in the crude extracts.

\subsection{Molecular analysis}

\subsubsection{DNA extraction and amplification}

Genomic DNA was extracted from 150 to $200 \mathrm{ml}$ of exponentially growing cultures, using the DNAeasy plant minikit (Qiagen, Genomics, Bothell, WA) following the manufacturer instructions. Amplification condition for genomic DNA and cloning strategy for PCR fragments are the same applied in Orsini et al., 2002). Sequences for the LSU rDNA were obtained with a Beckman Ceq 2000, using Dye-Terminator cycle sequencing kit (Beckman).

\subsubsection{Phylogenetic analysis}

P. galaxiae LSU sequences were aligned with LSU Pseudo-nitzschia sequences available in GenBank (Table 3). Cylindrotheca closterium and Nitzschia frustulum were used as outgroup and ingroup, re-

Table 3

List of diatom strains used for the LSU rDNA phylogeny with accession number to the informatic database GenBank

\begin{tabular}{|c|c|}
\hline Species & $\begin{array}{l}\text { GenBank } \\
\text { accession } \\
\text { number }\end{array}$ \\
\hline $\begin{array}{l}\text { Cylindrotheca closterium (Ehrenberg) Lewin \& } \\
\quad \text { Reimann }\end{array}$ & M87326 \\
\hline Nitzschia frustulum (Kutzing) Grunow & AF417671 \\
\hline P. americana (Hasle) Fryxell & U41390 \\
\hline P. australis Frenguelli & U41393 \\
\hline P. australis & U40850 \\
\hline P. australis (OM1) & AF417651 \\
\hline P. delicatissima (Cleve) Heiden & AF416748 \\
\hline P. delicatissima & AF416749 \\
\hline P. delicatissima & AF416758 \\
\hline P. delicatissima & U41391 \\
\hline P. delicatissima $(1001$ 2b) & AF417645 \\
\hline P. fraudulenta (Cleve) Hasle & AF416750 \\
\hline P. fraudulenta & AF416751 \\
\hline P. fraudulenta & AF416762 \\
\hline P. fraudulenta (Limens1) & AF417647 \\
\hline P. inflatula (Hasle) Hasle (No7) & AF417639 \\
\hline $\begin{array}{l}\text { P. micropora Priisholm, Moestrup \& Lundholm } \\
\text { (VPB-B3) }\end{array}$ & AF417649 \\
\hline
\end{tabular}

Table 3 (Continued)

\begin{tabular}{ll}
\hline Species & $\begin{array}{l}\text { GenBank } \\
\text { accession } \\
\text { number }\end{array}$ \\
\hline P. multiseries (Hasle) Hasle (OFPm984) & AF417655 \\
P. multiseries & $\mathrm{U} 41389$ \\
P. multistriata (Takano) Takano & $\mathrm{AF} 416753$ \\
P. multistriata & $\mathrm{AF} 416754$ \\
P. multistriata & $\mathrm{AF} 416756$ \\
P. multistriata & $\mathrm{AF} 416757$ \\
P. multistriata (Korea A) & $\mathrm{AF} 417654$ \\
P. pseudodelicatissima (Hasle) Hasle & $\mathrm{AF} 416747$ \\
P. pseudodelicatissima & $\mathrm{AF} 416752$ \\
P. pseudodelicatissima & $\mathrm{AF} 416755$ \\
P. pseudodelicatissima & $\mathrm{AF} 416759$ \\
P. pseudodelicatissima & $\mathrm{AF} 416760$ \\
P.cf. pseudodelicatissima (Hobart 5) & $\mathrm{AF} 417641$ \\
P. pseudodelicatissima (P-11) & $\mathrm{AF} 417640$
\end{tabular}

P. pseudodelicatissima SZN-B109AY550126

P. pseudodelicatissima SZN-B111AY550128

P. pseudodelicatissima SZN-B112AY550127

P. pseudodelicatissima SZN-B113AY550129

P. pungens (Grunow ex Cleve) Hasle U41392

$P$. pungens $\quad \mathrm{U} 41262$

P. pungens $(\mathrm{KBH} 2) \quad$ AF417650

P. pungens (P-24) AF417648

P. seriata (Cleve) Peragallo (Lynaes 8) AF417653

P. seriata (Nissum 3) AF417652

P. subfraudulenta (Hasle) Hasle AF416761

P. subfraudulenta Rensubfrau AF417646

P. cf. subpacifica (Hasle) Hasle (Zhenbo 7B) AF417644

P. cf. subpacifica (P-28) AF417643

P. cf. subpacifica (RdA8)

AF417642

P. galaxiae (Sydney) Lundholm \& Moestrup

P. galaxiae (Mexico)

P. galaxiae SZN-B54AY544786

P. galaxiae SZN-B55AY544791

P. galaxiae SZN-B56AY544790

P. galaxiae SZN-B57AY544789

P. galaxiae SZN-B58AY544788

P. galaxiae SZN-P1AY544787

P. galaxiae SZN-P5AY544792

SZN: strains isolated in the Gulf of Naples.

${ }^{\text {a }}$ Sequences kindly provided by N. Lundholm.

spectively. Both species are pennate diatoms and, according to the LSU rDNA phylogeny including Pseudo-nitzschia and close genera (Lundholm et al., 2002), the former is at the base of the clade grouping Pseudo-nitzschia species, while the latter clusters 
immediately out of the Nitzschia-Pseudo-nitzschia clade. The alignment was obtained using Clustal W (Thompson et al., 1994) in the Bioedit 4.5.8 computer package (Hall, 1999).

Distance analysis was performed using Bioedit 4.5.8 computer package (Hall, 1999); nucleotide polymorphism was calculated using DNAsp 3.0 version (Rozas and Rozas, 1999); phylogenetic relationships were inferred using both distance and parsimony analyses. The Neighbor-Joining (NJ) tree (Saitou and Nei, 1987) was assembled using the Kimura 2 parameter distance and getting the Neighbor option from MEGA 2.1 computer package (Kumar et al., 2001); the maximum parsimony trees were performed using the parsimony option in MEGA 2.1 (Kumar et al., 2001).

\section{Results}

\subsection{Morphology}

P. galaxiae cells from the Gulf of Naples are thin and weakly silicified (Figs. 1-2), the apical axis is 10-82 $\mu \mathrm{m}$ long (mean \pm S.D.: $41.14 \pm 17.70, n$ $=551$ ), the transapical axis is $1-1.8 \mu \mathrm{m}$ (mean \pm S.D.: $1.2 \pm 0.3, n=37$ ). In valve view, cells are lanceolate to needle-shaped, with a swelling in their central part. Two chloroplasts are placed in the central area (Fig. 1). In girdle view, cells have a linear outline and overlap of about $5-10 \%$ when forming stepped colonies (Fig. 1A). The eccentric raphe is characterized by the presence of the central larger interspace (Fig. 2B-D). Valves show 18-28 fibulae in $10 \mu \mathrm{m}$ and 54-68 striae in $10 \mu \mathrm{m}$. The striae do not have poroids and are perforated by small scattered pores, which are variable in number and generally more dense in the areas close to the interstriae (Fig. 2E). The proximal and distal mantle have the same structure as the valve face. The valves taper distally, ending with very thin $(0.2-0.6 \mu \mathrm{m})$ rostra; the opposite tips of the same valve show a similar structure (Fig. $2 \mathrm{~F}$ and G). The cingulum comprises three kinds of open bands, all with small scattered perforations and a silicified rib running along their length (Fig. 2H). The first cingular band, the valvocopula, has a pattern of striae similar to the valve on one or both sides of the rib. The copulae (one or two) are homogeneously silicified on both sides of the rib; the pleurae show a very irregular pattern of unsilicified stripes separated by branched silicified lines.

In addition to typical morphotypes, fitting the original description and size range of the species (25-41 $\mu \mathrm{m}$ ), both longer (up to $82 \mu \mathrm{m}$ ) and shorter (down to $10 \mu \mathrm{m}$ ) morphotypes were observed in the material from the Mediterranean Sea. Differences in
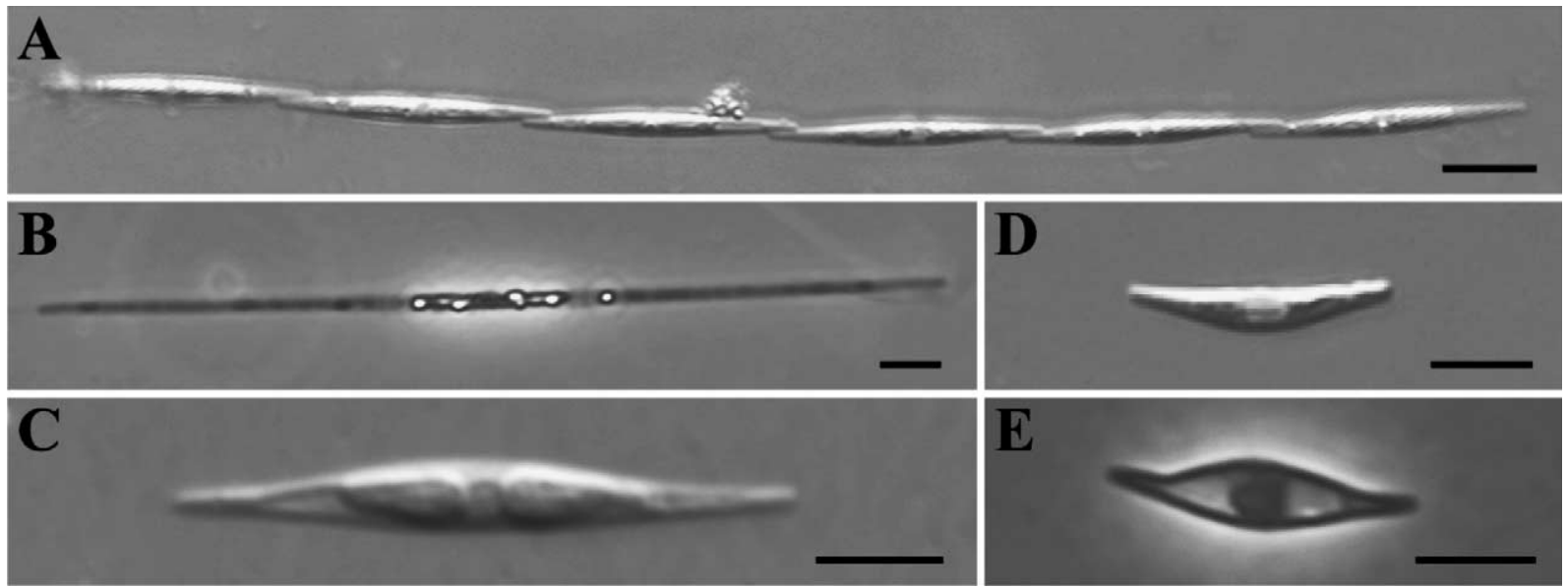

Fig. 1. Light micrographs of $P$. galaxiae from the Gulf of Naples. (A) Chain of medium-sized specimens. Culture material, differential interference contrast (DIC). (B) A long-sized specimen with almost linear valve outline. Natural material (August, 2002), phase contrast (PC). (C) A medium-sized specimen showing the typical lanceolate outline with a swelling in the central part. Culture material, DIC. (D) and (E) Small-sized specimens; note the shorter rostra and the oval outline in the smallest one (E). Culture material, (D) DIC, (E) PC. Scale bars: (A) $10 \mu \mathrm{m}$; (B)-(E) $5 \mu \mathrm{m}$. 


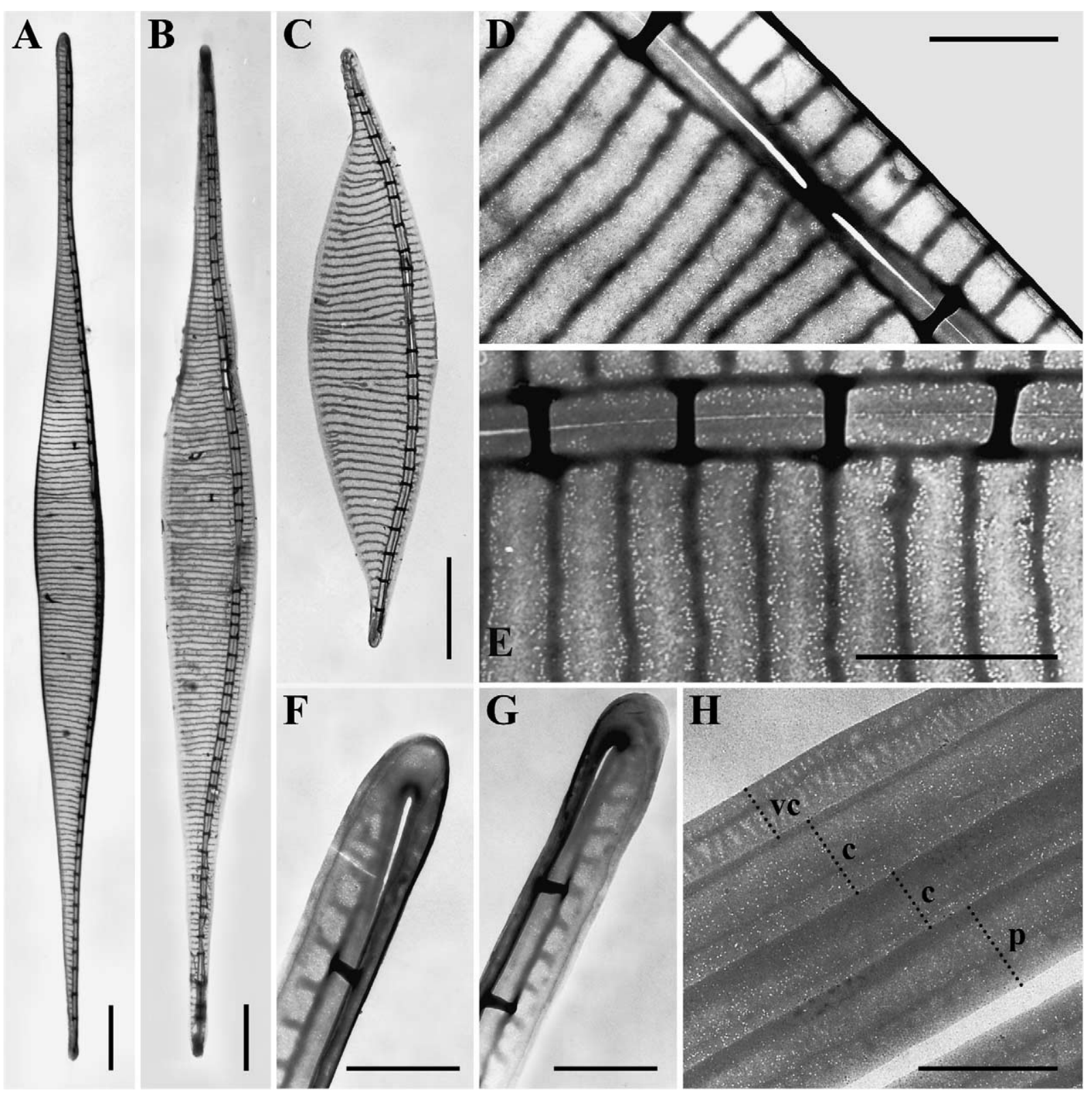

Fig. 2. Electron micrographs of $P$. galaxiae from the Gulf of Naples, culture material. (A) and (B) Valves of long-sized specimens. (C) Valve of a small-sized specimen. (D) Central part of a valve with the central larger interspace. (E) Detail of a valve; note the typical small and scattered poroids. (F) and (G) Opposite ends of the same valve. (H) Cingulum with a valvocopula (vc), two copulae (c) and one pleura (p). Scale bars: (A)-(C) $2 \mu \mathrm{m}$; (D)-(H) $0.5 \mu \mathrm{m}$.

cell length are due to the variable extension of the rostra, resulting in distinct cell shapes. While the medium-sized specimens are lanceolate in shape, with clearly rostrate ends (Fig. 1A and C), larger speci- mens tend to lose the lanceolate outline (Fig. 1B), having valves with almost parallel margins. In small specimens, the rostra become shorter (Fig. 1D) and in the smallest ones the whole cell assumes an oval 


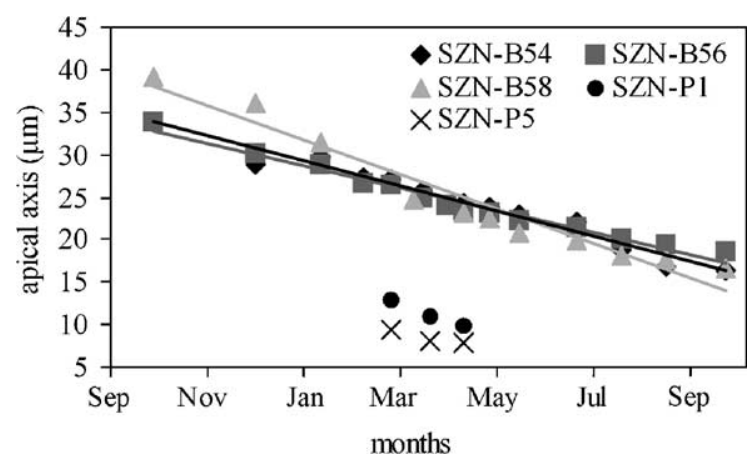

Fig. 3. Reduction of the apical axis length in five strains of $P$. galaxiae, September, 2001-September, 2002.

outline, with a gradual or abrupt tapering of the ends (Fig. 1D and E). The boundaries between the length of different morphotypes are approximately 20-25 $\mu \mathrm{m}$ for the small to medium and $45-50 \mu \mathrm{m}$ for the medium to long morphotype transitions. All different morphotypes show identical ultrastructural features (Fig. 2A-C).

Strains brought into culture from the Gulf of Naples belonged to the medium- (strains SZN-B54, SZN-B55, SZN-B56, SZN-B57, SZN-B58) and small(strains SZN-P1, SZN-P5) sized morphotypes. While medium-sized morphotypes formed stepped colonies of up to 14 specimens in culture plates, the small ones were observed as single cells or rarely in couplets. $P$. galaxiae cultures showed a constant decrease in the average cell size over the time (Fig. 3). The cell size decrease was of 1.3-2.0 $\mu \mathrm{m}$ per month for the larger clones and 1.1-2.1 $\mu \mathrm{m}$ per month for the smaller ones.

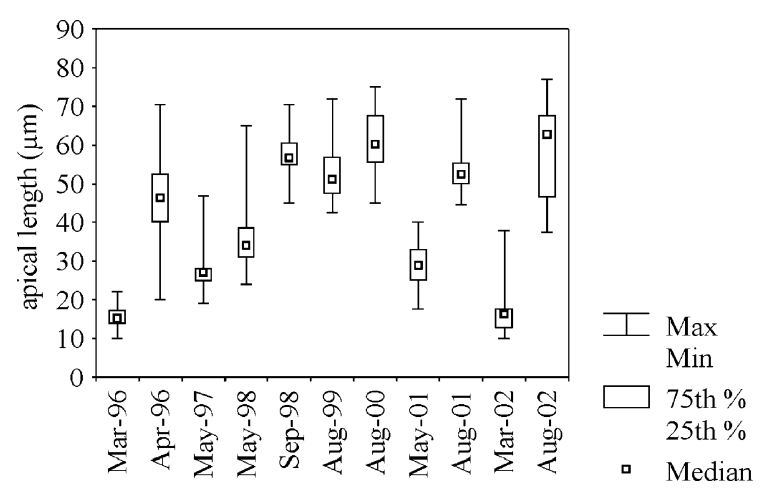

Fig. 5. Length (apical axis) of P. galaxiae in natural samples from the Gulf of Naples.

\subsection{Distribution}

In the Gulf of Naples, $P$. galaxiae was recorded from February to November, in correspondence with $T$ and $S$ values of $13.3-28.1^{\circ} \mathrm{C}$ and $36.6-38.2$ psu. A first annual increase was usually recorded in February-March

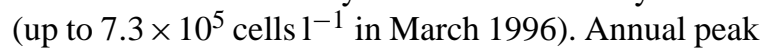

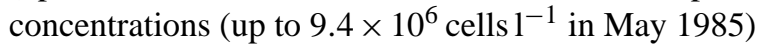
generally occurred in May and August (Fig. 4). Generally, cells of different size classes did not occur all together in the same sample (Fig. 5). The first annual increase in late winter-early spring was prevalently due to the smaller morphotypes, with rarer records of the medium-sized ones (Fig. 6). In late spring blooms, the medium-sized morphotypes dominated, whereas in August-September most specimens were longer than $50 \mu \mathrm{m}$. The small morphotype always occurred as

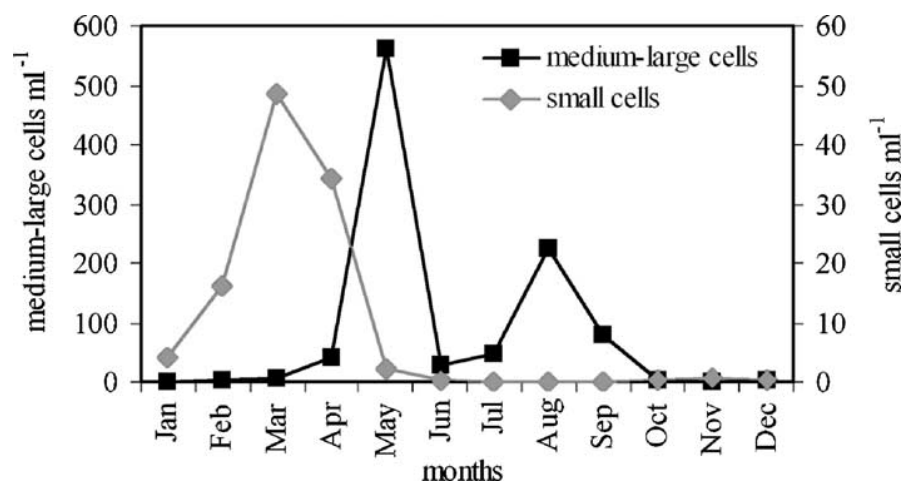

Fig. 4. Multiannual monthly averages (1984-1991; 1995-2002) of cell concentrations of long-medium (black squares) and small (gray diamonds) $P$. galaxiae in the Gulf of Naples. 


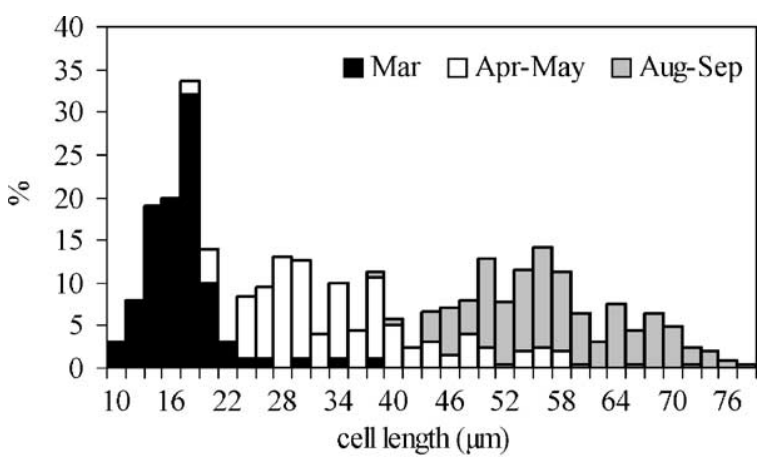

Fig. 6. Length percentage distribution of $P$. galaxiae in the Gulf of Naples during the three peak phases. Sampling dates considered are the same as in Fig. 5.

single cells, whereas the medium and long morphotypes where at times seen in colonies, although the solitary habit prevailed at all sizes.

$P$. galaxiae is apparently widespread in both open and coastal waters of the Mediterranean Sea. In addition to the Gulf of Naples, the species was recorded in the open Sicily Channel, the Olbia harbour (north-western Tyrrhenian Sea), the north-western
Mediterranean, offshore the Balearic Islands, and the Adriatic Sea. Identification at all these sites was confirmed by electron microscopy. A specimen $14 \mu \mathrm{m}$ long is documented in an EM picture of a sample from the Sicily Channel (November 1991). The other samples were relatively homogeneous in terms of size and colonial habits. In the North Balearic Sea material (March 2003), small solitary specimens (10-20 $\mu \mathrm{m}$ in apical axis) were recorded in fixed samples and in dilution cultures. Material from the Adriatic Sea (May 2002) mostly consisted of colonial specimens in the upper size-range, whereas samples from Olbia (June 2002) had mainly medium-sized colonial specimens.

\subsection{Toxicity}

LC-MS analysis in positive SIM mode of the SPE eluates showed a chromatographic peak with the same retention time of DA in two samples of the seven strains examined, namely, SZN-B54 (Fig 7a) and SZN-B56.

Both positive and negative multiple reaction monitoring (MRM) experiments provided further confirmation allowed detection of DA also in the crude extracts
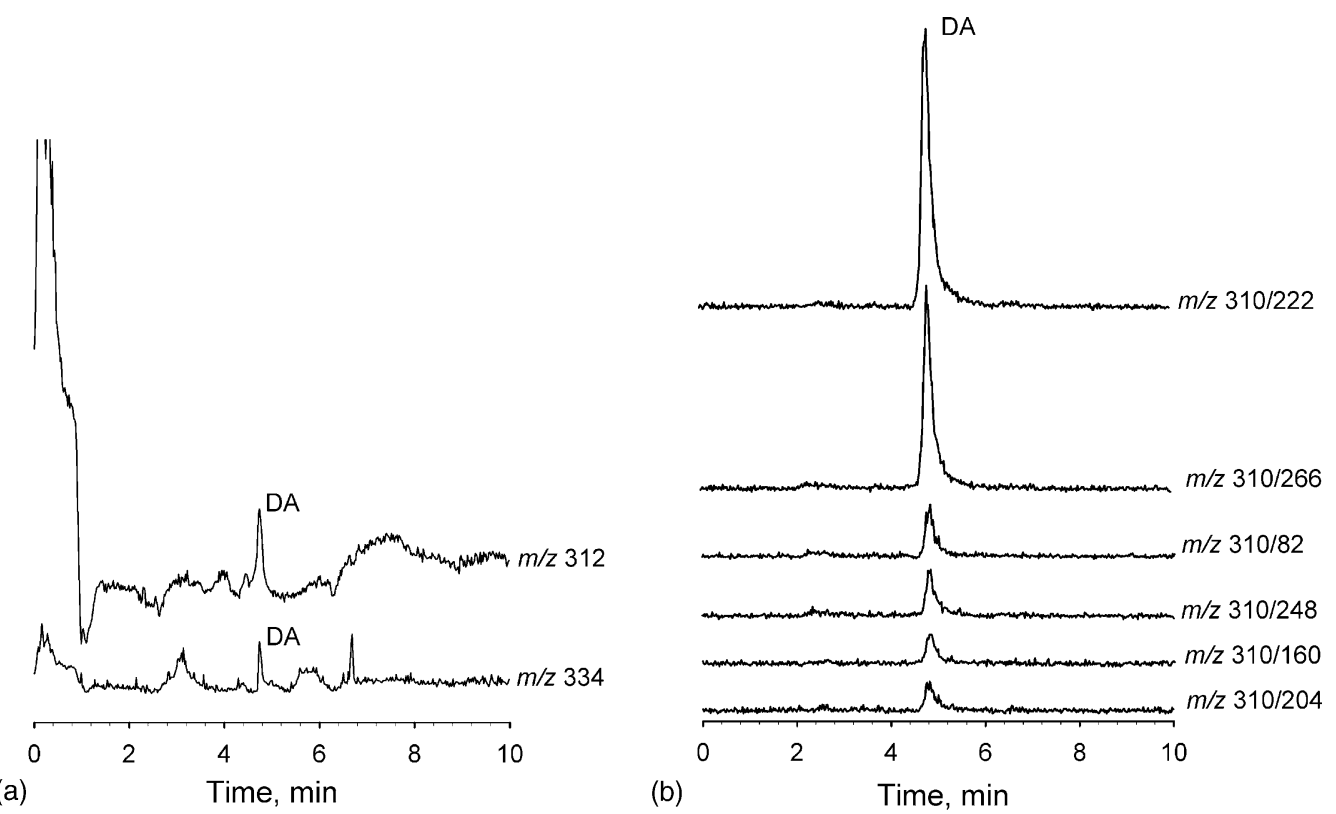

Fig. 7. LC-MS analyses of: (a) the SZN-B54 SPE eluate in SIM positive ion mode and (b) the SZN-B54 crude extract in MRM negative ion mode. Chromatographic conditions were as in Section 2. 
of the two positive strains (Fig. 7b). The retention time (4.80 min), the presence of six diagnostic fragments for DA in both ionization modes and the ion ratios were fully consistent with the presence of DA in the two positive samples.

The comparison with a DA standard revealed concentration values of $3.6 \times 10^{-4}$ and $7.8 \times 10^{-7}$ pg per cell in SZN-B54 and SZN-B56 samples, respectively.

\subsection{LSU rDNA phylogeny}

The alignment of the sequences did not present difficulties along the $868 \mathrm{bp}$ of the D1-D3 domains of the LSU rDNA. A very low level of polymorphism was found within the seven $P$. galaxiae from the Gulf of Naples, with only three mutations detected. The percentage of polymorphic sites was 0.1 ; any site was parsimony informative. The strains of $P$. galaxiae from the Gulf of Naples were almost identical (0.0001 genetic distance). When the strains of $P$. galaxiae from Sydney and Mexico were added to the Neapolitan ones, the percentage of polymorphic sites increased to 0.4 .

The total alignment, in which all Pseudo-nitzschia species were considered, shows 86 polymorphic sites, 55 of which were parsimony informative. $P$. galaxiae sequences shared 10 point mutation; eight of these are also present in other Pseudo-nitzschia species, while two (450 and $460 \mathrm{bp}$ in the alignment) were unique to the species (synapomorphy) (Table 4).

The Neighbor-Joining and Maximum Parsimony trees, built on the total alignment, showed the same topology. The NJ tree, with both bootstrap and parsimony values, is shown in Fig. 8. The phylogenetic relationships among strains of the same species had high bootstrap support, while the branches did not have bootstrap support at supraspecific level. All strains of $P$. galaxiae clustered together to form a strongly supported clade, within which the strains from the Gulf of Naples and those from other areas formed two separate subclades.

Pseudo-nitzschia pseudodelicatissima strains showed a peculiar phylogenetic position in the LSU rDNA analysis. Only four of the nine strains from the Gulf of Naples (P. pseudodelicatissima I) clustered together with strains from other areas. Four other strains (P. pseudodelicatissima II) formed a clearly distinct, all-Neapolitan clade. Finally, the strain SZN-B26 ( $P$. pseudodelicatissima III) was found alone in a position in the tree not clearly resolved. The Pseudo-nitzschia delicatissima clade was relatively more homogenous, though it included a strain of P. micropora. For other Pseudo-nitzschia species, such as Pseudo-nitzschia fraudulenta and Pseudo-nitzschia multistriata, strains of the same species clustered together, independently from their geographic origin. P. multistriata formed a well supported group, while the separation between P. fraudulenta and Pseudo-nitzschia subfraudulenta was not well supported. Pseudo-nitzschia pungens and Pseudo-nitzschia multiseries strains formed two soundly distinct groups, as did Pseudo-nitzschia seriata and Pseudo-nitzschia australis. Pseudo-nitzschia americana sit alone at the base of a larger clade including the species $P$. pungens, $P$. multiseries, $P$. multistriata, P. seriata and P. australis. Pseudo-nitzschia inflatula sit at the base of the phylogenetic tree, separated from the all other Pseudo-nitzschia species.

\section{Discussion}

\subsection{Morphology}

As compared with the original description (Lundholm and Moestrup, 2002), specimens of $P$. galaxiae from the Mediterranean Sea have exactly the same ultrastructural features, i.e. the number of fibulae and striae and the presence of a fine perforation

Table 4

Sites of mutations shared by $P$. galaxiae strains

\begin{tabular}{lllllllllll}
\hline & \multicolumn{1}{l}{ Position $5^{\prime}-3^{\prime}$} \\
\cline { 2 - 11 } & 140 & 202 & 448 & 450 & 460 & 462 & 504 & 555 & 565 & 567 \\
\hline P. galaxiae & A & C & T & T & A & G & T & T & T & A \\
Others Pseudo-nitzschia species & A/G & G/T/A/C & G/A/T & C & G & T/C/G & T/C & G/A/T & G/A/T/C & T/A/C \\
\hline
\end{tabular}

Mutations in sites 450 and 460 are unique to $P$. galaxiae. 


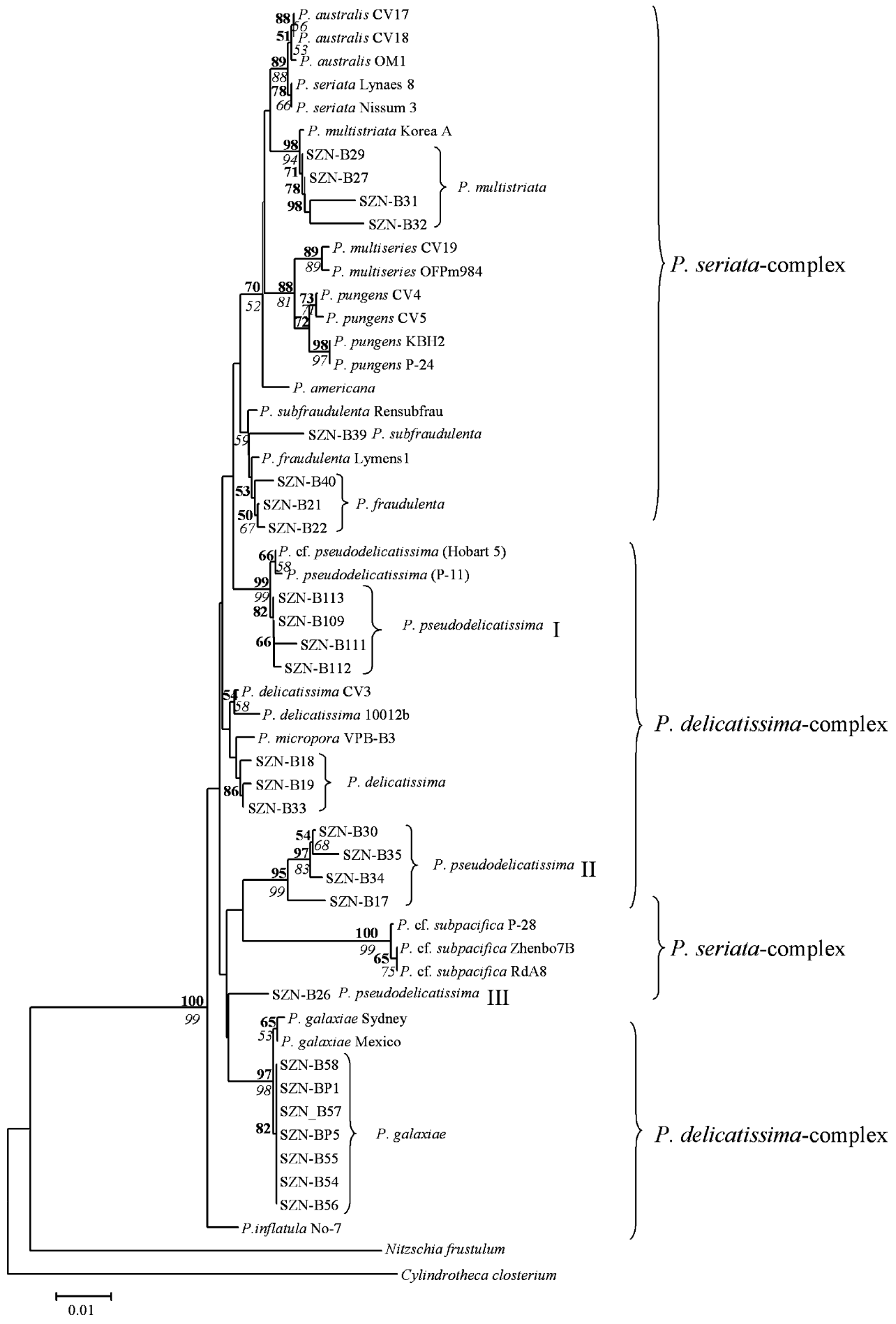

Fig. 8. Neighbor-Joining tree inferred from D1-D3 hypervariable domains of the nuclear LSU rDNA for 53 taxa, one ingroup and one outgroup. Bootstrap values $>50 \%$ are shown in boldface above branches. Parsimony values are shown in italics below branches. 
on the valve and bands. However, the Mediterranean $P$. galaxiae showed a very wide range of size and shape variability. A change in shape due to the shortening of the rostrate ends had already been noticed in cells over the size range of 25-41 $\mu \mathrm{m}$ (Lundholm and Moestrup, 2002). In the Mediterranean material, the shape change was so extreme that the smallest individuals $(10-25 \mu \mathrm{m})$ could hardly be identified as Pseudo-nitzschia.

The observed morphological variability was strictly related to size reduction, which in diatoms is associated with vegetative cell divisions. Variations in shape with reducing size are not uncommon in pennate diatoms, where the transapical axis decreases proportionally much more than the apical axis. This phenomenon is more pronounced in cells with rostrate ends (Round et al., 1990), which could explain why it is much more remarkable in $P$. galaxiae as compared to other Pseudo-nitzschia species with linear valve outlines. Among centric diatoms, the bipolar Cymatosiraceae represent one of the most striking cases of shape variability, whereby size reduction involves the change of valve outline from a lanceolate, pennate-type to a subcircular, centric-type shape, which involves both a reduction in the transapical axis and an increase in the apical axis. The variation in valve size and shape in Cymatosiraceae would not allow to attribute different morphotypes to the same species if they had not been studied in cultures (Hasle et al., 1983). The same can be said for $P$. galaxiae, with a further complication due to the fact that in natural samples the different morphotypes do not occur at the same time.

Chain formation was not observed in cultures of smaller specimens of $P$. galaxiae. The cell extremities are probably too short to allow a suitable overlap for a stable colony formation. Intraspecific variability in colony formation also occurs in other diatoms, e.g. Cerataulina pelagica (Cleve) Hendy, Leptocylindrus danicus Cleve and Chaetoceros socialis Lauder. In the Cymatosiraceae, variability in colony formation is generally not related to size, except for Minutocellus Hasle, von Stosch and Syvertsen species, where, differently from $P$. galaxiae, only cells with a smaller transapical axis form colonies (Hargraves and Guillard, 1974).

P. galaxiae represents the extreme case of intraspecific size, shape and colony-formation variability among all the Pseudo-nitzschia species. In P. deli- catissima, which is another abundant species in the Gulf of Naples, transapical length values comparable to the minimum ones of $P$. galaxiae can be attained in cultured strains (D'Alelio and Montresor, unpublished data). However, such small specimens of $P$. delicatissima have never been found in the Gulf of Naples, nor reported from elsewhere, which means that they either cannot survive or they do not reach detectable concentrations in the natural environment.

As discussed by Lundholm and Moestrup (2002), the thin, lanceolate valve shape of $P$. galaxiae is also found in other Pseudo-nitzschia species. In samples from the Gulf of Naples, long and medium-sized specimens of $P$. galaxiae were conventionally identified as $P$. cf. prolongatoides on the basis on their shape. The latter species, which can form stellate colonies besides typical stepped colonies (Hasle, 1965) has never been reported from anywhere else other than Antarctic waters. $P$. granii (Hasle) Hasle also has a lanceolate shape with a central swelling. In some samples from the Adriatic Sea, thin and delicate P. delicatissima specimens were found which were difficult to distinguish from long-sized $P$. galaxiae. However, in all these congeneric species the frustule has poroids and not the fine perforations typical of $P$. galaxiae. As compared with other Pseudo-nitzschia, P. galaxiae is also extremely thin and delicate, due to a very weak silicification. These features, coupled with the tendency to be solitary or to form very short colonies, could imply a lower cost for buoyancy and be an advantage in stratified waters such as those of the Gulf of Naples in late spring-summer (Ribera d'Alcalà et al., 2004).

The wide size and shape variability of $P$. galaxiae in natural samples can be a source of misidentification even at the genus level. Before this investigation, the smallest specimens blooming in early spring in the Gulf of Naples had been tentatively classified as Phaeodactylum tricornutum Bohlin, and indeed the pennate stages of the latter species are very similar to small $P$. galaxiae, although they possess only one chloroplast. P. tricornutum is one of the most widely used diatoms in laboratory experiments, yet its distribution in the natural environment is not known. In the Mediterranean Sea, the species is reported from several areas, including the Catalan Sea (Estrada, 1980; Margalef, 1995), the Gulf of Marseille (Travers, 1975), the Tyrrhenian Sea (Puddu et al., 1983), the 
Ionian Sea (Rabitti et al., 1994) and the Lebanese coasts (Abboud-Abi Saab, 1985). However, the resemblance with $P$. galaxiae throws doubt on the value of those identifications that have been based on light microscopy observations. On the other hand, long specimens of $P$. galaxiae are not easily distinguished from C. closterium (Ehrenberg) Lewin \& Reimann, which at times is found with straight instead of typically curved ends. The two species tend to occur together and at comparable concentrations in summer samples of the Gulf of Naples (unpublished data), making their classification rather troublesome. All these identification problems could be the reason for the lack of previous records of $P$. galaxiae, which otherwise appears rather widely distributed in the Mediterranean Sea, based on our data.

\subsection{Toxicity}

Domoic acid was detected in two out of the seven cultures examined, at extremely low concentration values. These values were much lower than those found in the only other species from the Gulf of Naples found to be toxic, P. multistriata (Orsini et al., 2002), which were already among the lowest recorded in the literature (Bates, 1998). However, the present results indicate for the first time $P$. galaxiae as a toxic species, potentially responsible for harmful algal blooms, which is in contrast with previous results obtained on other strains (Lundholm and Moestrup, 2002). Likely, this difference could be due to the high sensitivity of the LC-MS method employed and particularly to the high selectivity of MRM technique, due to elimination of signals from other co-extractives. However, variations for toxin productivity in different $P$. galaxiae strains or at different physiological conditions cannot be ruled out. In fact some of the clones which were found non toxic in this analysis could have been genetically identical to those revealed as toxic, since they derived from the same dilution culture tubes from which toxic strains had been isolated.

In the analysis of potentially toxic species, particular attention must be paid to the analytical method employed in order to avoid false negative due to the low instrument sensitivity or high detection limits of the method rather than to a real non-toxicity of the species. The LC-MS method employed has great potential for further investigation of domoic acid in other
Pseudo-nitzschia spp. so far thought to be non-toxic. In particular, MRM acquisition mode is recommended because it is highly selective, very sensitive and presents almost zero background signal in the chromatograms. The potential to produce DA even at very low levels is important information for management purposes, especially considering that the rate of DA production can vary with the physiological state of the cells and can be strongly affected by environmental conditions (Pan et al., 1998; Maldonado et al., 2002).

\subsection{Phylogeny}

The LSU phylogeny confirms that the species found in the Gulf of Naples is indeed P. galaxiae and that, independent of size and shape, all strains examined are strictly related. The overall intraspecific genetic diversity in $P$. galaxiae is lower than in other Pseudo-nitzschia species (Orsini et al., 2002). The Neapolitan strains could be so similar because most of them derive from the same sample; however, the low level of polymorphism shown by the non Neapolitan strains suggests that $P$. galaxiae has a lower intraspecific diversity as compared to other Pseudo-nitzschia species (Orsini et al., 2002).

All strains of $P$. galaxiae, independent of their geographic origin, share some characteristic sites along the alignment of the LSU rDNA (Table 4). Two sites were unique to $P$. galaxiae and close enough each other to allow the design of a species-specific molecular probe (Scholin et al., 1996). Probes could be a useful tool in this species given its high morphological variability and the likelihood of misidentifications.

When moving from the species level to the whole phylogeny of the genus Pseudo-nitzschia, a lack of resolution is evident. In previous studies (Lundholm et al., 2002; Orsini et al., 2002), the lack of resolution was attributed to the limited number of sequences considered. However, the use of more species and strains in the present analysis did not improve the resolution at the supraspecific level, rather it produced some additional ambiguous results. In particular, the unclear phylogenetic position of $P$. pseudodelicatissima was evident, with strains occurring in three distinct clades (P. pseudodelicatissima I, II and III). P. pseudodelicatissima has been described as non-homogeneous from the morphological standpoint, with at least two morphotypes which are distinguished on the base of 
the pattern of the poroids within striae (Hasle, 1965; Hallegraeff, 1994). Poroids can either be tetra- or hexa-partited, forming a kind of rose-window pattern, or bipartited. Interestingly, the poroids of $P$. pseudodelicatissima I from the Gulf of Naples were all bipartited, whereas those of clade II and III showed a typical rose-window pattern. This indicates that at least two but possibly three distinct species could be hidden in $P$. pseudodelicatissima, as already pointed out by Hasle (2002). The use of multiple and/or more sensitive molecular markers coupled with a more detailed morphological analysis are required to clarify the taxonomy of this taxon. The lack of clearly distinctive features and the ultrastructural variability in some taxa could also be an indication of recent speciation in these planktonic pennates that should be investigated also using cross-fertilization experiments.

\subsection{Seasonal size distribution}

Mean cell size in diatoms generally decreases at each cell division during the phase of vegetative growth. When a critical minimum size is reached, the maximum cell dimensions are restored through auxosporulation (Mann, 1988; Round et al., 1990). Auxospore formation is rarely observed in situ (Mann, 1988), therefore size variations over time are often the only hint of sexual reproduction (Mann, 2002). Information on diatom life cycles in the natural environment is very poor, being mainly limited to a few pennate (Mann, 1988) or centric species (Rojo et al., 1999) from ponds or small lakes. These investigations have shown that, within a population, sexual reproduction is a nearly synchronous event which occurs within a restricted size window, with a periodicity varying from 2 to 40 years (Mann, 1988). Frequent sampling and a huge number of size measurements over several years are hence required in order to detect sexual reproduction. However, tracking size variations is a particularly difficult task in the case of planktonic species, due to the spatial and temporal overlapping of distinct cohorts in the natural environment (Mann, 1988).

The peculiar seasonal size distribution recurrently observed for $P$. galaxiae offers the basis for some hypotheses on the life cycle of this species in the Gulf of Naples. The early-spring peak of the P. galaxiae morphotypes that attain the minimum cell size is particularly interesting. These populations, which are presumably the oldest ones, are expected to reproduce sexually to restore the maximum size. However, no large-sized cells that could be the product of sexual reproduction were observed together with small cells in early spring. This could mean that sexual reproduction occurs at extremely low rate in this season, possibly because cells are too small, most of them being $12-24 \%$ of the known maximum size. In P. multiseries, the lowest limit of the reproductive size window is $23 \%$ of the maximum size (Hiltz et al., 2000). If sexual reproduction does not occur, cells would grow vegetatively until death, as observed in culture. Alternatively, sexual reproduction could occur somewhere else, e.g. in deeper, thin water layers, but this seems less probable, since the water column in the sampling area is thoroughly mixed in winter-early spring.

Another hypothesis could be that sexual reproduction occurs over a wide size range and does not always restore the maximum size for the species. This occurs in other pennate species, for which a correlation between the size of the parent cells and that of the auxospores and daughter cells has been demonstrated (Davidovich, 1994). The few medium-sized $P$. galaxiae cells observed in early spring, and possibly those blooming in May could derive from the small-sized populations of early spring. In turn, the medium-sized morphotypes that dominate the late-spring blooms could undergo sexual reproduction and originate cells of large size that bloom in August-September. Since the upper limit of the reproductive size window has been found to be much higher than previously thought, up to $70 \%$ of the maximum size in P. multiseries (Hiltz et al., 2000), sexual reproduction could also occur in a wide size range in $P$. galaxiae.

The relationships between the $P$. galaxiae populations of one year with those of the next year are unclear. Based on an average size decrease of $2 \mu \mathrm{m}$ per month, it would take several years for the late-summer, maximum-size population of $70-80 \mu \mathrm{m}$ to reach the early-spring size of $10-15 \mu \mathrm{m}$. This size reduction rate was observed at a growth rate of ca. 0.9 divisions per day (A. Amato and M. Montresor, unpublished data), which was obtained at moderate light intensities and 12:12 photoperiod. However, growth and size-reduction rates could fluctuate over the year in the natural environment, but in any case the small-cell population is presumably at least 2-years old. These values for size reduction rates and maximum age are 
comparable to those of ca. 3 years calculated, for example in P. multiseries (Davidovich and Bates, 1998).

All these hypotheses require support from sound information on sexual reproduction, reproductive size windows, maximal cell size attained, reduction rates under different conditions and all other aspects of the life cycle of $P$. galaxiae. The relationship existing between size and life cycle highlights the interest of gathering data on cell size distribution in natural samples to keep trace of the life cycle.

Marked changes in size and shape distribution were observed among the three peak periods of $P$. galaxiae, i.e. early spring, late spring and summer. In the Gulf of Naples, these periods are characterized by very distinct conditions of temperature, water column stability, nutrient and light availability, and by different phyto- and zooplankton populations (Ribera d'Alcalà et al., 2004). Hence, significant physiological and ecological differences probably exist among $P$. galaxiae morphotypes. In another diatom, Chaetoceros curvisetus Cleve, cells of different size show distinct physiological responses to temperature (Furnas, 1978), which may lead to blooms of selected size classes under changing environmental conditions. Physiological differences, as well as different environmental conditions, could also have implications for DA production in natural populations of $P$. galaxiae (Bates, 1998), with consequent variations of their toxicity over the year.

From an evolutionary perspective, the variability in size, shape and colony formation throughout the life cycles can be seen as an optimal strategy for diatoms to colonize a wide range of ecological niches. On the other hand, the discontinuity observed between the blooms dominated by distinct morphotypes could be interpreted as a temporal segregation of demes that would lead to speciation. Based on strains isolated in a restricted period of the year, we demonstrated that there is molecular homogeneity and morphological continuity between medium and small-sized morphotypes. However, we cannot exclude that molecular differences and reproductive isolation exist or will exist among populations blooming in different periods of the year. Molecular investigations extended over the year, coupled with laboratory studies of the physiology and life cycle are required to shed light on the relationships between morphology, ecology and physiology of this very interesting diatom species.

\section{Acknowledgements}

The toxin analysis is part of a research supported by MURST PRIN, Rome, Italy.

\section{References}

Abboud-Abi Saab, M., 1985. Étude quantitative et qualitative du phytoplancton des eaux cotières libanaises. Lebanese Sci. Bull. $1,197-222$.

Bates, S.S., 1998. Ecophysiology and metabolism of ASP toxin production. In: Anderson, D.M., Cembella, A.D., Hallegraeff, G.M. (Eds.), Physiological Ecology of Harmful Algal Blooms. Springer-Verlag, Berlin, pp. 405-426.

Bates, S.S., Bird, C.J., Freitas, A.S.W.D., Foxall, R., Gilgan, M.W., Hanic, L.A., Johnson, J.E., McCulloch, A.W., Odense, P., Pocklington, R., Quilliam, M.A., Sim, P.G., Smith, J.C., Rao, D.V.S., Todd, E.C.D., Walter, J.A., Wright, J.L.C., 1989. Pennate diatom Nitzschia pungens as the primary source of domoic acid, a toxin in shellfish from eastern Prince Edward Island. Canadian J. Fish. Aquat. Sci. 46, 1203-1215.

Davidovich, N.A., 1994. Factors controlling the size of initial cells in diatoms. Russian J. Plant Physiol. 41, 220-224.

Davidovich, N.A., Bates, S., 1998. Sexual reproduction in the pennate diatom Pseudo-nitzschia multiseries and P. pseudodelicatissima (Bacillariophyceae). J. Phycol. 34, 126-137.

Estrada, M., 1980. Composición taxonómica del fitoplancton en una zona próxima a la desembocadura del río Besós (Barcelona), de octubre de 1978 a marzo de 1979. Invest. Pesq. 44, 275-289.

Furnas, M., 1978. Influence of temperature and cell size on the division rate and chemical content of the diatom Chaetoceros curvisetum Cleve. J. Exp. Mar. Biol. Ecol. 34, 97-109.

Guillard, R.R.L., 1983. Culture of phytoplankton for feeding marine invertebrates. In: Berg, C.J.J. (Ed.), Culture of Marine Invertebrates Selected Readings. Hutchinson Ross Publishing Co., Stroudsbero, PA, pp. 108-132.

Hall, T.A., 1999. BioEdit: a user-friendly biological sequence alignment editor and analysis program for Windows 95/98/NT. Nucl. Acids Symp. Ser. 41, 95-98.

Hallegraeff, G.M., 1994. Species of the diatom genus Pseudonitzschia in Australian waters. Bot. Mar. 37, 397-411.

Hargraves, P.E., Guillard, R.R.L., 1974. Structural and physiological observations on some small marine diatoms. Phycologia 13, 163-172.

Hasle, G.R., 1965. Nitzschia and Fragilariopsis species studied in the light and electron microscopes. Part II. The group Pseudonitzschia. Skr. Nor. Vidensk-Akad. Oslo Part I. Mat-Naturvidensk. K1. 18, 1-45.

Hasle, G.R., 1995. Pseudo-nitzschia pungens and P. multiseries (Bacillariophyceae): nomenclatural history, morphology and distribution. J. Phycol. 31, 428-435.

Hasle, G.R., 2002. Are most of the domoic acid-producing species of the diatom genus Pseudo-nitzschia cosmopolites. Harmful Algae 1, 137-146. 
Hasle, G.R., von Stosch, H.A., Syvertsen, E.E., 1983. Cymatosiraceae, a new diatom family. Bacillaria 6, 9-156.

Hiltz, M., Bates, S.S., Kaczmarska, I., 2000. Effect of light:dark cycles and cell apical length on the sexual reproduction of the pennate diatom Pseudo-nitzschia multiseries (Bacillariophyceae) in culture. Phycologia 39, 59-66.

Issel, R., 1934. Ciclo annuale del microplancton di superficie nel golfo di Napoli (golfo interno) (Introduzione illustrata all'indagine ecologica). Pubbl. Stn. Zool. Napoli 14, 1-50.

Kumar, S., Tamura, K., Jakobsen, I.B., Nei, M., 2001. MEGA2: Molecular Evolutionary Genetics Analysis software. Arizona State University, Tempe, AZ, USA.

Lundholm, N., Moestrup, Ø., 2002. The marine diatom Pseudonitzschia galaxiae sp. nov. (Bacillariophyceae), morphology and phylogenetic relationships. Phycologia 41, 594-605.

Lundholm, N., Daugbjerg, N., Moestrup, O., 2002. Phylogeny of the Bacillariaceae with emphasis on the genus Pseudo-nitzschia (Bacillariophyceae) based on partial LSU rDNA. Eur. J. Phycol. 37, 115-134.

Maldonado, M.T., Highes, M.P., Rue, E.L., 2002. The effect of $\mathrm{Fe}$ and $\mathrm{Cu}$ on growth and domoic acid production by Pseudo-nitzschia multiseries and Pseudo-nitzschia australis. Limnol. Oceanogr. 47, 515-526.

Mann, D.G., 1988. Why didn't Lund see sex in Asterionella? A discussion of the diatom life cycle in nature. In: Round, F.E. (Ed.), Algae and the Aquatic Environment, vol. 29. Biopress, Bristol, pp. 385-412.

Mann, D.G., 2002. Diatom life cycles. In: Garcés, E., Zingone, A., Montresor, M., Reguera, B., Dale, B. (Eds.), LIFEHAB: Life History of Microalgal Species Causing Harmful Blooms. European Commission, Brussels, pp. 13-17.

Margalef, R., 1995. Fitoplancton del NW del Mediteraneo (Mar Catalan) en junio del 1993, y factores que condicionan su producción y distribucción. Mem. R. Acad. Ciencias Artes Barcelona 60, 3-56.

Moestrup, Ø., Codd, G.A., Elbrächter, M., Faust, M.A., Fraga, S., Fukuyo, Y., Cronberg, G., Halim, Y., Taylor, F.J.R., Zingone, A., 2002. IOC taxonomic reference list of toxic algae. Intergovernmental Oceanographic Commission of UNESCO, http://www.ioc.unesco.org/hab/data4taxlist.

Orsini, L., Sarno, D., Procaccini, G., Poletti, R., Dahlmann, J., Montresor, M., 2002. Toxic Pseudo-nitzschia multistriata (Bacillariophyceae) from the Gulf of Naples: morphology, toxin analysis and phylogenetic relationships with other Pseudo-nitzschia species. Eur. J. Phycol. 37, 247-257.

Pan, Y., Bates, S.S., Cembella, A.D., 1998. Environmental stress and domoic acid production by Pseudo-nitzschia: a physiological perspective. Nat. Toxins 6, 127-135.

Puddu, A., Lombardi, F., Sequi, R., 1983. Distribuzione ed evoluzione delle comunità planctoniche. Quad. Ist. Ric. Acque 66, 169-199.

Quilliam, M.A., Hess, P., Dell'Aversano, C., 2001. Recent developments in the analysis of phycotoxins by liquid chromatography-mass spectrometry. In: deKoe, W.J., Samson, R.A., van Egmond, H.P., Gilbert, J., Sabino, M. (Eds.), Mycotoxins and Phycotoxins in Perspective at the Turn of the Millenium. Wageningen, The Neatherlands, pp. 383-391.
Quilliam, M.A., Xie, M., Hardstaff, W.R., 1995. Rapid extraction and cleanup for liquid chromatographic determination of domoic acid in unsalted seafood. J. AOAC Int. 78, 543-554.

Rabitti, S., Bianchi, F., Boldrin, A., Ros, L.D., Socal, G., Totti, C., 1994. Particulate matter and phytoplankton in the Ionian Sea. Oceanol. Acta 17, 297-307.

Ribera d'Alcalà, M., Conversano, F., Corato, F., Licandro, P., Mangoni, O., Marino, D., Mazzocchi, M.G., Modigh, M., Montresor, M., Nardella, M., Saggiomo, V., Sarno, D., Zingone, A., 2004. Seasonal patterns in plankton communities in a pluriannual time series at a coastal Mediterranean site (Gulf of Naples): an attempt to discern recurrences and trends. Sci. Mar. 68, 65-83.

Rojo, C., Kiss, K.T., Alvarez-Cobelas, M., Rodrigo, M.A., 1999. Population dynamics of Cyclotella ocellata (Bacillariophyceae): endogenous and exogenous factors. Arch. Hydrobiol. 145, 479495.

Round, F.E., Crawford, R.M., Mann, D.G., 1990. The Diatoms-Biology \& Morphology of the Genera. Cambridge University Press, Cambridge.

Rozas, J., Rozas, R., 1999. DnaSP version 3: an integrated program for molecular population genetics and molecular evolution analysis. Bioinformatics 15, 174-175.

Saitou, N., Nei, M., 1987. The Neighbor-Joining method: a new method for reconstructing phylogenetic trees. Mol. Biol. Evol. 4, 406-425.

Scholin, C.A., Buck, K.R., Britschgi, T., Cangelosi, G., Chavez, F.P., 1996. Identification of Pseudo-nitzschia australis (Bacillariophyceae) using rRNA-targeted probes in whole cells and sandwich hybridization formats. Phycologia 35, 190197.

Scholin, C.A., Gulland, F., Doucette, G.J., Benson, S., Busman, M., Chavez, F.P., Cordaro, J., DeLong, R., Vogetaere, A.D., Harvey, J., Haulena, M., Lefebvre, K., Lipscomb, T., Loscutoff, S., Lowenstine, L.J., Marin III, R., Miller, P.E., McLellan, W.A., Moeller, P.D.R., Powell, C.L., Rowles, T., Silvagni, P., Silver, M., Spraker, T., Trainer, V., Van Dolah, F.M., 2000. Mortality of sea lions along the central California coast linked to a toxic diatom bloom. Nature 403, 80-84.

Schröder, B., 1901. Das Phytoplankton des Golfes von Neapel nebst vergleichenden Ausblicken auf das des atlantischen Ozeans. Mitth. Zool. Stat. Neapel 14, 1-38.

Shumway, S.E., Allen, S.M., Dee Boersma, P., 2003. Marine birds and harmful algal blooms: sporadic victims or under-reported events. Harmful Algae 2, 1-17.

Thompson, J.D., Higgins, D.G., Gibbson, T.J., 1994. Clustal W: improving the sensitivity of progressive multiple sequence alignment through sequence weighting, position-specific gap penalities and weight matrix choice. Nucl. Acids Res. 22, 46734680.

Travers, M., 1975. Inventaire des protistes du Golfe de Marseille et de ses parages. Ann. Inst. Oceanogr. Paris 51, 51-75.

Utermöhl, H., 1958. Zur vervollkommnung der quantitativen phytoplankton-methodik. Mitt. Int. Ver. Theor. Angew. Limnol. 9, 1-38.

Zingone, A., Licandro, P., Nardella, M., Sarno, D., 2002. Seasonality and interannual variation in the occurrence of 
species of the genus Pseudo-nitzschia in the Gulf of Naples (Mediterranean Sea). In: Abstract Book of the 10th International Conference on Harmful Algae, St. Pete Beach, FL, US, 21-25 October 2002, p. 315.
Zingone, A., Licandro, P., Sarno, D., 2003. Revising paradigms and myths of phytoplankton ecology using biological time series. In: Briand, F. (Ed.), Mediterranean Biological Time Series. CIESM Workshop Monographs no. 22, Monaco, pp. 109-114. 